\title{
Determinan Pemberian ASI Eksklusif: Analisis Data Sekunder Survei Demografi dan Kesehatan 2017
}

\section{Determinants of Exclusive Breastfeeding: Secondary Analysis Data of Indonesian Demographic and Health Survey 2017}

\author{
Adilah Anindito Difa Putri*1, Salsabila Naim ${ }^{1}$
}

\begin{abstract}
ABSTRAK
Latar Belakang: Angka Kematian Bayi merupakan salah satu masalah kesehatan utama di Indonesia. Pemberian ASI eksklusif kepada bayi merupakan salah satu cara efektif agar dapat menurunkan Angka Kematian Bayi di Indonesia. Cakupan ASI eksklusif pada tahun 2017 sebesar 52\%, hal tersebut telah memenuhi minimal 50\% dari target nasional namun cakupan ASI eksklusif menurun seiring dengan pertambahan usia anak.

Tujuan: Penelitian ini bertujuan untuk menentukan faktor yang mempengaruhi pemberian ASI eksklusif di Indonesia. Metode: Penelitian ini menggunakan data sekunder dari Survei Demografi dan Kesehatan Indonesia 2017 dengan desain cross-sectional. Sampel penelitian berjumlah 1.435 yang terdiri dari ibu yang memiliki anak berusia 0-5 bulan terakhir yang masih hidup, tidak memiliki anak kembar, tinggal bersama anaknya dan masih menyusui. Analisis data berupa analisis bivariabel dengan metode chi-square dan analisis multivariabel dengan metode regresi logistik berganda.

Hasil: Ibu yang memiliki anak berusia $0-1$ bulan 22,835 kali berpeluang lebih tinggi untuk memberikan ASI eksklusif dibanding ibu yang memiliki anak berusia $4-5$ bulan, hal yang sama berlaku pada ibu yang memiliki anak berusia $2-3$ bulan berpeluang tinggi untuk memberikan ASI eksklusif. Ibu dengan pendidikan tinggi 3,383 kali berpeluang lebih tinggi untuk memberikan ASI eksklusif dibanding ibu yang tidak sekolah, hal yang sama berlaku pada ibu dengan pendidikan menengah dan ibu dengan pendidikan dasar berpeluang tinggi untuk memberikan ASI eksklusif. Ibu dengan tingkat status ekonomi atas 1,670 kali berpeluang lebih tinggi untuk memberikan ASI eksklusif dibanding ibu dengan tingkat status ekonomi bawah, hal yang sama berlaku pada ibu dengan tingkat status ekonomi menengah berpeluang tinggi untuk memberikan ASI eksklusif.

Kesimpulan: Hasil penelitian menunjukkan bahwa faktor yang mempengaruhi pemberian ASI eksklusif yaitu: usia anak, tingkat pendidikan ibu dan status ekonomi.
\end{abstract}

Kata Kunci: ASI Eksklusif, Determinan, Data Sekunder

\section{ABSTRACT}

Background: Infant Mortality Rate is one of the main health problems in Indonesia. Exclusive breastfeeding for infants is one of the effective ways in order to lower the infant mortality rate in Indonesia. Exclusive breastfeeding coverage in 2017 was $52 \%$, this has met at least $50 \%$ of the national target, but exclusive breastfeeding coverage decreases with increasing age of the child.

Objectives: This study aims to determine the factors that influence exclusive breastfeeding in Indonesia.

Methods: This study used secondary data from Indonesian Demographic and Health Survey in 2017 with cross-sectional design. The research sample was 1,435 consisting of mothers who have children aged 0-5 months who were still alive, did not have twins, living with their children and were still breastfeeding. Data analysis was in the form of bivariable analysis using the chi-square method and multivariable analysis using multiple logistic regression methods.

Result: Mothers who have children aged 0 - 1 month 22.835 times have a higher chance of giving exclusive breastfeeding than mothers who have children aged 4 - 5 months, the same applies to mothers who have children aged 2 - 3 months have a high chance of giving exclusive breastfeeding. Mothers with higher education were 3.383 times more likely to provide exclusive breastfeeding than mothers who did not go to school, the same was true for mothers with secondary education and mothers with primary education had a high chance of exclusive breastfeeding. Mothers with upper economic status level are 1.670 times more likely to provide exclusive breastfeeding than mothers with lower economic status.

Conclusion: The results showed that the factors affecting exclusive breastfeeding were: child's age, mother's education level and economic status.

Keywords: Exclusive Breastfeeding, Determinants, Secondary Data 


\author{
"Korespondensi: \\ adilah.anindito.difa-2016@fkm.unair.ac.id* \\ Adilah Anindito Difa Putri \\ ${ }^{1}$ Fakultas Kesehatan Masyarakat, Universitas Airlangga \\ Jl. Mulyorejo Surabaya, Indonesia \\ Diterbitkan Oleh Universitas Airlangga dan IAGIKMI
}

\section{PENDAHULUAN}

Angka Kematian Bayi (AKB) merupakan salah satu indikator penting dalam menilai derajat kesehatan masyarakat. Tingginya AKB sebesar 24 kematian per 1.000 kelahiran $^{1}$ merupakan satu diantara banyaknya masalah kesehatan utama di Indonesia, sehingga banyak program kesehatan Indonesia yang dibuat sebagai upaya penurunan AKB. Cara yang dapat digunakan untuk menurunkan angka kematian bayi yaitu pemberian ASI eksklusif yang bisa mengurangi $13 \%$ angka kematian anak dan sekitar $50-60 \%$ kematian anak dibawah 5 tahun disebabkan oleh malnutrisi dan menyusui yang kurang optimal².

ASI eksklusif adalah pemberian ASI kepada bayi, tanpa adanya cairan atau padatan lain yang diberikan bahkan air terkecuali larutan tetes/sirup vitamin, mineral atau obat-obatan. Menyusui secara eksklusif direkomendasikan hingga anak berusia 6 bulan, setelahnya dapat dilanjutkan dengan pemberian ASI bersamaan dengan makanan pendamping yang sesuai hingga usia dua tahun atau lebih ${ }^{3}$. ASI eksklusif sangatlah penting bagi bayi, hal tersebut dibuktikan dengan kebijakan nasional yang tertuang dalam Peraturan Pemerintah Republik Indonesia Nomor 33 Tahun 2012 mengenai program pemberian ASI eksklusif 4 .

Pemberian ASI eksklusif bagi bayi sangatlah diperlukan dikarenakan terdapat beberapa manfaat yang dapat diperoleh yaitu: membantu tumbuh-kembang otak bayi, meningkatkan sistem kekebalan tubuh anak, melindungi dari berbagi penyakit infeksi dikarenakan ASI mengandung antibodi, melindungi anak dari berbagi penyakit lainnya (alergi, influenza, difteri, diare, obesitas, diabetes,limfoma dan leukimia), memperkecil risiko terjadinya SIDS dan postneonatal death dan menjaga kesehatan kardiovaskular anak hingga masa dewasa. Pemberian ASI eksklusif juga berguna bagi ibu yaitu membantu menjalin ikatan batin antara ibu dan bayi, meningkatkan rasa percaya diri ibu yang telah berhasil memberikan ASI eksklusif (hal yang terbaik) kepada bayinya dan mengurangi risiko terkena kanker payudara ${ }^{5}$. Hasil Survei Demografi dan Kesehatan Indonesia tahun 2017 menunjukkan bahwa persentase ASI eksklusif untuk anak berumur di bawah 6 bulan meningkat dalam 5 tahun terakhir sebesar $11 \%$ yaitu dari 42\% pada tahun 2012 menjadi 52\% pada tahun 2017. Capaian ASI eksklusif juga memenuhi target minimal 50\% yang telah ditetapkan dalam rencana pembangunan nasional lima tahun terakhir. Namun, persentase ASI eksklusif menurun seiring dengan pertambahan usia anak. Persentase ASI eksklusif anak usia di bawah 1 bulan yaitu $67 \%$, kemudian turun menjadi $55 \%$ pada anak usia 2-3 bulan dan menurun lagi menjadi 38\% pada anak usia 4-5 bulan ${ }^{1}$.

Pemberian ASI eksklusif dipengaruhi dari berbagai macam faktor, salah satunya berkaitan erat dengan teori perilaku yang digagas oleh Lawrence Green. Menurut Green di Notoatmodjo, terdapat dua determinan perilaku manusia, yairu faktor perilaku dan faktor non-perilaku 6 . Berdasarkan hal tersebut, Green menambahkan tiga faktor utama yang mempengaruhi perilaku kesehatan yaitu faktor predisposisi, faktor pendukung dan faktor penguat. Faktor-faktor predisposisi dalam pemberian ASI eksklusif antara lain faktor sosiodemografi (umur, pendidikan, pekerjaan, tempat tinggal dan status ekonomi), pengetahuan, sikap, keyakinan dan sebagainya. Faktor-faktor pendukung dalam pemberian ASI eksklusif antara lain akses informasi, sarana kesehatan, tempat persalinan, penolong persalinan, dan sebagainya. Faktor-faktor penguat dalam pemberian ASI eksklusif adalah dukungan yang diberikan teman, keluarga, petugas kesehatan dan sebagainya. Berdasarkan latar belakang yang telah dipaparkan, sehingga penelitian ini dilakukan untuk menganalisis faktor yang mempengaruhi pemberian ASI eksklusif di Indonesia menggunakan data SDKI tahun 2017.

\section{METODE}

Penelitian ini adalah penelitian deskriptif analitik dengan rancangan penelitian cross-sectional yang menggunakan data sekunder. Pengumpulan data bersumber dari hasil Survei Demografi dan Kesehatan Indonesia (SDKI) tahun 2017. Survei Demografi dan Kesehatan Indonesia merupakan survei berskala nasional yang dilaksanakan bersama oleh Badan Pusat Statistik (BPS), Badan Kependudukan dan Keluarga Berencana Nasional (BKKBN) dan Kementrian Kesehatan (Kemenkes). SDKI bertujuan untuk memberikan gambaran menyeluruh mengenai kependudukan serta kesehatan ibu dan anak di Indonesia. Pengambilan data berlangsung selama 24 Juli - 30 September 2017 yang dilakukan oleh tim petugas lapangan dengan mewawancarai responden dengan kuesioner. Pengolahan data dilakukan setelah semua kuesioner SDKI 2017 telah diisi dan dikirim ke BPS Pusat di Jakarta selanjutnya hasil SDKI 2017 disajikan dalam bentuk laporan ${ }^{1}$. SDKI 2017 yang berada dibawah naungan Demograhic and Health Surveys (DHS) Program telah melalui proses pengkajian dan mendapatkan persetujuan dari ICF International Review Board (IRB). Penelitian ini menggunakan data SDKI 2017 yang didapatkan dari situs web dan telah mendapat perizinan dari pihak DHS Program.

Populasi pada penelitian ini merupakan seluruh wanita usia subur usia 15 - 49 tahun di Indonesia menurut SDKI tahun 2017 yang berjumlah 49.627. Sampel pada penelitian ini merupakan bagian dari populasi dengan beberapa kriteria inklusi yaitu: ibu berusia 15-49 tahun yang memiliki anak terakhir usia $0-5$ bulan yang masih hidup, tidak memiliki anak kembar, tinggal bersama anaknya dan masih menyusui. Besar sampel 
yang didapatkan sebesar 1.435. Data yang tidak lengkap tidak diikutkan dalam analisis.

Variabel dependen dalam penelitian ini yaitu pemberian ASI eksklusif yang terdapat pada informasi sosio-demografi antara lain: usia ibu, usia anak, tingkat pendidikan ibu, status pekerjaan ibu, daerah tempat tinggal dan status ekonomi (wealth index) sedangkan faktor pendukung antara lain: kunjungan antenatal care (ANC), jenis persalinan, tempat persalinan dan inisiasi menyusui dini (IMD). Variabel independen yang diteliti tersebut diukur melalui jawaban responden berdasarkan kuesioner terstruktur SDKI 2017.

Usia ibu dalam penelitian ini dibagi menjadi 3 kelompok yaitu $15-19$ tahun, $20-34$ tahun dan 35-49 tahun. Usia anak juga dibagi menjadi 3 kelompok yaitu 0 -1 bulan, $2-3$ bulan dan $4-5$ bulan. Tingkat pendidikan ibu dibagi menjadi 4 kelompok yaitu tidak sekolah, dasar (SD - SMP), menengah (SMA) dan tinggi (perguruan tinggi). Status pekerjaan ibu dibagi menjadi 2 kategori yaitu bekerja dan tidak bekerja. Daerah tempat tinggal dibagi menjadi 2 kategori yaitu pedesaan dan perkotaan. Tingat status ekonomi dibagi berdasarkan indeks kekayaan dan pada penelitian ini klasifikasi tingkat status ekonomi dibagi menjadi 3 kategori yaitu tingkat status ekonomi atas, tingkat status ekonomi menengah dan

\section{HASIL DAN PEMBAHASAN}

Berdasarkan tabel 1 memperlihatkan bahwa mayoritas ibu berada pada kelompok usia $20-34$ tahun sebanyak $74,0 \%$. Mayoritas usia anak berada pada kelompok usia $2-3$ bulan sebesar $37,2 \%$, diikuti kelompok usia 4 - 5 bulan sebesar $35,7 \%$ dan sebesar $27,1 \%$ berada pada kelompok usia $0-1$ bulan. Tingkat pendidikan ibu didominasi dengan ibu yang memiliki tingkat pendidikan menengah sebesar $56,4 \%$, diikuti tingkat pendidikan dasar sebesar 23,3\%, tingkat pendidikan tinggi sebesar $19,1 \%$ dan tidak sekolah sebesar $1,2 \%$. Mayoritas status pekerjaan ibu berada pada kategori tidak bekerja sebesar 58,5\%. Daerah tempat tinggal mayoritas berada di pedesaan sebesar $56,0 \%$. Tingkat status ekonomi didominasi tingkat status ekonomi bawah sebesar 50,3\%, diikuti tingkat status ekonomi atas sebesar $31,8 \%$ dan tingkat status ekonomi riwayat pemberian makanan dan minuman dalam 24 jam terakhir pada bayi usia $0-5$ bulan. Variabel independen dalam penelitian ini terdiri dari faktor predisposisi dan faktor pendukung. Faktor predisposisi terdiri dari faktor tingkat status ekonomi bawah. Kunjungan ANC dibagi menjadi 2 kategori yaitu ya (melakukan kunjungan ANC minimal 1 kali selama kehamilan) dan tidak (tidak melakukan kunjungan ANC sama sekali selama kehamilan). Jenis persalinan dibagi menjadi 2 kategori yaitu persalinan normal dan persalinan sesar. Tempat persalinan dibagi menjadi 3 kelompok yaitu rumah, fasilitas kesehatan dan lainnya. IMD dibagi menjadi 2 kategori yaitu $\leq 1$ jam dan $>1$ jam.

Analisis data meliputi analisis univariabel, bivariabel dan multivariabel. Analisis univariabel bertujuan untuk menggambarkan karakteristik masingmasing variabel. Analisis bivariabel menggunakan metode chi-square yang dilakukan untuk seleksi variabel dengan $p<0,05$. Tahap akhir dilakukan analisis multivariabel menggunakan metode regresi logistik berganda dengan Confidence Interval (CI) 95\% dan tingkat kemaknaan $p<0,05$ untuk menentukan apakah variabel independen yang diuji termasuk sebagai determinan pemberian ASI eksklusif.

menengah sebesar 17,8\%. Mayoritas ibu melakukan kunjungan antenatal care selama kehamilannya sebesar $96,7 \%$. Jenis persalinan didominasi dengan persalinan secara normal sebesar $83,7 \%$. Mayoritas tempat persalinan dilakukan di fasilitas kesehatan sebesar $76,4 \%$. Mayoritas Inisiasi Menyusui Dini dilakukan dalam periode waktu $\leq 1$ jam sebesar $62,0 \%$.

Berdasarkan informasi pada tabel 1 dari hasil uji chi-square, didapatkan variabel independen yang akan diuji dengan regresi logistik berganda terdapat tiga variabel yaitu usia anak, tingkat pendidikan ibu dan status ekonomi. Tabel 2 menunjukkan hasil uji regresi logistik berganda untuk menentukan determinan pemberian ASI eksklusif di Indonesia. Kategori "ASI eksklusif" digunakan sebagai referensi dalam uji regresi logistik berganda pada penelitian ini. 
Tabel 1 Statistik Deskriptif dan Uji Chi-Square antara Pemberian ASI Eksklusif dan Variabel yang Berkaitan

\begin{tabular}{|c|c|c|c|c|}
\hline \multirow[b]{2}{*}{ VARIABEL } & \multicolumn{2}{|c|}{ Pemberian ASI } & \multirow[b]{2}{*}{$\begin{array}{c}\text { Semua } \\
(\%)\end{array}$} & \multirow[b]{2}{*}{$p$-value } \\
\hline & $\begin{array}{c}\text { ASI Eksklusif } \\
\text { (\%) }\end{array}$ & $\begin{array}{c}\text { Tidak ASI Eksklusif } \\
\text { (\%) }\end{array}$ & & \\
\hline \multicolumn{5}{|l|}{ Usia Ibu (tahun) } \\
\hline $15-19$ & 5,1 & 1,5 & 6,6 & \multirow{3}{*}{0,144} \\
\hline $20-34$ & 62,9 & 11,1 & 74,0 & \\
\hline $35-49$ & 16,7 & 2,8 & 19,4 & \\
\hline \multicolumn{5}{|l|}{ Usia Anak (bulan) } \\
\hline $0-1$ & 26,6 & 0,6 & 27,1 & \multirow{3}{*}{$>0,001$} \\
\hline $2-3$ & 33,9 & 3,3 & 37,2 & \\
\hline $4-5$ & 24,3 & 11,4 & 35,7 & \\
\hline \multicolumn{5}{|c|}{ Tingkat Pendidikan Ibu } \\
\hline Tidak Sekolah & 0,8 & 0,4 & 1,2 & \multirow{4}{*}{$>0,001$} \\
\hline Dasar & 18,5 & 4,8 & 23,3 & \\
\hline Menengah & 47,8 & 8,6 & 56,4 & \\
\hline Tinggi & 17,6 & 1,5 & 19,1 & \\
\hline \multicolumn{5}{|l|}{ Status Pekerjaan Ibu } \\
\hline Bekerja & 35,3 & 6,3 & 41,5 & \multirow[t]{2}{*}{0,897} \\
\hline Tidak Bekerja & 49,4 & 9,1 & 58,5 & \\
\hline \multicolumn{5}{|c|}{ Daerah Tempat Tinggal } \\
\hline Pedesaan & 46,9 & 9,1 & 56,0 & \multirow[t]{2}{*}{0,285} \\
\hline Perkotaan & 37,8 & 6,2 & 44,0 & \\
\hline \multicolumn{5}{|l|}{ Status Ekonomi } \\
\hline Atas & 28,9 & 3,0 & 31,8 & \multirow{3}{*}{$>0,001$} \\
\hline Menengah & 14,6 & 3,2 & 17,8 & \\
\hline Bawah & 41,2 & 9,1 & 50,3 & \\
\hline \multicolumn{5}{|l|}{ Kunjungan ANC } \\
\hline Ya & 82,2 & 14,6 & 96,7 & \multirow[t]{2}{*}{0,175} \\
\hline Tidak & 2,5 & 0,8 & 3,3 & \\
\hline \multicolumn{5}{|l|}{ Jenis Persalinan } \\
\hline Normal & 70,2 & 13,4 & 83,7 & \multirow[t]{2}{*}{0,097} \\
\hline Operasi sesar & 14,4 & 1,9 & 16,3 & \\
\hline \multicolumn{5}{|l|}{ Tempat Persalinan } \\
\hline Rumah & 19,1 & 4,4 & 23,5 & \multirow{3}{*}{0,136} \\
\hline Faskes & 65,5 & 10,9 & 76,4 & \\
\hline Lainnya & 0,0 & 0,1 & 0,1 & \\
\hline \multicolumn{5}{|l|}{ IMD } \\
\hline$\leq 1 \mathrm{Jam}$ & 52,8 & 9,3 & 62,0 & \multirow[t]{2}{*}{0,656} \\
\hline >1 Jam & 31,9 & 6,1 & 38,0 & \\
\hline
\end{tabular}

Tabel 2 memperlihatkan bahwa usia anak, tingkat pendidikan ibu dan tingkat status ekonomi sebagai determinan pemberian ASI eksklusif. Ibu yang memiliki anak berusia $0-1$ bulan memiliki peluang 22,835 kali lebih tinggi untuk memberikan ASI eksklusif dibanding ibu yang memiliki anak berusia $4-5$ bulan (Cl $95 \% 11,033-47,261)$, begitu pula pada ibu yang memiliki anak yang berusia $2-3$ bulan memiliki peluang sebesar 5,014 kali lebih tinggi dibanding ibu yang memiliki anak berusia $4-5$ bulan untuk memberikan ASI eksklusif (Cl 95\% 3,504-7,175). Dengan demikian, dapat disampaikan bahwa semakin muda usia anak maka semakin besar kemungkinan ibu untuk memberikan ASI eksklusif begitupun sebaliknya bahwa semakin bertambahnya usia anak maka semakin rendah kemungkinan ibu untuk memberikan ASI eksklusif.

Hasil penelitian ini sesuai dengan beberapa penelitian antara lain pada penelitian Suparmi \& Saptarini $(2012)^{7}$ yang menyatakan bahwa usia anak berpengaruh pada pemberian ASI eksklusif. Penelitian Onah, Osuorah,
Ebenebe, Ezechukwu, Ekwochi et al $(2014)^{8}$ juga menemukan bahwa usia anak berpengaruh pada pemberian ASI eksklusif dan menurunnya pemberian ASI eksklusif diikuti dengan bertambahnya usia anak. Hasil SDKI (2017) ${ }^{1}$ dan Riskesdas $(2018)^{9}$ menunjukkan hal yang sama bahwa semakin muda usia anak menyebabkan terjadinya peningkatan presentasi pemberian ASI eksklusif, sebaliknya bahwa seiring bertambahnya usia anak mengakibatkan semakin menurunnya presentasi pemberian ASI eksklusif.

Penurunan peluang pemberian ASI eksklusif dengan bertambahnya usia anak dapat dihubungkan dengan masa cuti bersalin pada ibu yang mana standar pemberian cuti melahirkan yaitu tiga bulan sehingga hal tersebut menjadi tantangan bagi ibu yang bekerja dalam memberikan ASI eksklusif kepada sang bayi ${ }^{7}$. Pemberian makanan pendamping ASI (MP-ASI) turut mempengaruhi ASI eksklusif dikarenakan pemahaman ibu yang berpendapat bahwa ASI kurang mencukupi kebutuhan nutrisi bayi sehingga ibu memperkenalkan makanan 
pendamping ASI (MP-ASI) lebih awal kepada bayi, padahal ASI dapat mencukupi kebutuhan nutrisi bayi selama enam bulan pertama kehidupannya dan masih bisa mencukupi sekitar sepertiga kebutuhan kalori bayi pada usia dua tahun ${ }^{7}$. Selain itu jarak kelahiran yang pendek memungkinkan ibu hamil kembali dan mengganti ASI eksklusif menjadi susu formula seperti kasus di negara berkembang, sehingga menjadikan durasi pemberian ASI eksklusif berkurang pada bayi dalam usia enam bulan ${ }^{10}$.

Tabel 2 Analisis Multivariabel Determinan Pemberian ASI Eksklusif pada Anak Usia 0 - 2 Tahun

\begin{tabular}{lcccc}
\hline \multicolumn{1}{c}{ Variabel } & B & $\boldsymbol{p}$-value & OR & Cl 95\% \\
\hline Usia Anak (bulan) & & $>\mathbf{0 , 0 0 1}$ & & \\
$0-1$ & 3,128 & 0,000 & 22,835 & $11,033-47,261$ \\
$2-3$ & 1,612 & 0,000 & 5,014 & $3,504-7,175$ \\
$4-5$ (referensi) & & & & \\
Tingkat Pendidikan Ibu & & $\mathbf{0 , 0 0 6}$ & & \\
Tidak Sekolah (referensi) & & & & \\
Dasar & 0,259 & 0,659 & 1,295 & $0,411-4,084$ \\
Menengah & 0,697 & 0,228 & 2,008 & $0,646-6,245$ \\
Tinggi & 1,219 & 0,050 & 3,383 & $0,999-11,461$ \\
Status Ekonomi & & $\mathbf{0 , 0 1 8}$ & & \\
Bawah (referensi) & & & & \\
Menegah & $-0,144$ & 0,490 & 0,866 & $0,574-1,304$ \\
Atas & 0,513 & 0,016 & 1,670 & $1,102-2,529$ \\
\hline
\end{tabular}

Tabel 2 menunjukkan bahwa ibu dengan pendidikan tinggi 3,383 kali memiliki peluang lebih tinggi untuk memberikan ASI eksklusif dibanding ibu yang tidak sekolah (Cl 95\% 0,999-11,461). Ibu dengan pendidikan menengah memiliki peluang sebesar 2,008 kali lebih tinggi dibanding ibu yang tidak sekolah untuk memberikan ASI eksklusif (Cl 95\% 0,646 - 6,245). Ibu dengan pendidikan dasar memiliki peluang sebesar 1,295 kali lebih tinggi untuk memberikan ASI eksklusif dibanding ibu yang tidak sekolah (Cl 95\% 0,411 - 4,084). Berdasarkan deskripsi diatas dapat disampaikan bahwa semakin tinggi tingkat pendidikan ibu maka semakin tinggi peluang ibu memberikan ASI eksklusif kepada bayi, begitupun sebaliknya bahwa semakin rendah tingkat pendidikan ibu maka semakin rendah peluang ibu memberikan ASI eksklusif kepada bayi.

Hasil penelitian ini didukung dari beberapa penelitian yaitu pada penelitian Ulfah, Sahli, Nusadewiarti \& Angraini (2014) ${ }^{11}$ mengatakan bahwa pendidikan ibu memiliki hubungan yang signifikan dengan pemberian ASI eksklusif. Penelitian Lindawati (2019) ${ }^{12}$ juga mengatakan bahwa pendidikan ibu memiliki hubungan yang bermakna dengan pemberian ASI eksklusif. Penelitian Mogre, Dery \& Gaa (2016) ${ }^{13}$ menyatakan bahwa ibu dengan tingkat pendidikan yang tinggi berhubungan dengan peluang pemberian ASI eksklusif yang lebih tinggi.

Pendidikan membuat penerapan pemberian ASI eksklusif menjadi lebih mudah dikarenakan ibu yang terpelajar akan mengerti mengenai keuntungan dari ASI eksklusif. Pendidikan juga berperan penting dalam mengurus tugas rumah tangganya termasuk dalam mengurus anggota keluarganya, salah satunya pemberian ASI eksklusif yang memegang peranan penting dalam menjaga kesehatan dan tumbuh kembang sang anak. Pendidikan juga meningkatkan kesadaran mengenai kesehatan dan secara positif mempengaruhi perilaku pencarian kesehatan (health seeking behavior), salah satunya pemberian ASI eksklusif yang sangat bermanfaat bagi bayinya ${ }^{14}$. Selain itu, ibu yang berpendidikan cenderung lebih memahami pesan yang diterima selama pembicaraan kesehatan ketika kunjungan antenatal care (ANC) dan cenderung juga memiliki lebih banyak akses informasi dari media dan materi lain yang mempromosikan praktik menyusui yang optimal15. Sehingga, ibu yang berpendidikan tinggi cenderung lebih berupaya dalam mencari perawatan medis, lebih tahu tentang kebutuhan gizi anak-anak mereka, dan mengadopsi praktik kesehatan yang lebih baik ${ }^{16}$.

Tabel 2 menginformasikan bahwa ibu dengan tingkat status ekonomi atas berpeluang 1,670 kali lebih tinggi untuk memberikan ASI eksklusif dibanding ibu dengan tingkat status ekonomi bawah (Cl 95\% 1,102 $2,529)$, hal yang sama berlaku pada ibu dengan tingkat status ekonomi menengah memiliki peluang sebesar 0,866 kali lebih tinggi untuk memberikan ASI eksklusif dibanding ibu dengan tingkat status ekonomi bawah (Cl $95 \% 0,574-1,304)$. Berdasarkan deskripsi diatas dapat disampaikan bahwa tingkat status ekonomi atas memiliki peluang yang tinggi untuk ibu memberikan ASI eksklusif dibanding kategori status ekonomi lainnya. Hasil penelitian ini serupa dengan hasil penelitian Tariku, Alemu, Gizaw, Muchie, Derso et al (2017) ${ }^{17}$ yang menemukan bahwa tingkat status ekonomi berpengaruh dalam pemberian ASI eksklusif dan kemungkinan meningkatnya pemberian ASI eksklusif berjalan seiring dengan tingkat status ekonomi yang tinggi, dimana pada penelitian tersebut tercatat bahwa tingkat status ekonomi yang tinggi memiliki peluang lebih tinggi dalam pemberian ASI eksklusif diantara kategori status ekonomi yang lain (OR 1,34; Cl 95\% 1,07-1,65).

Tingkat status ekonomi (wealth index) merupakan indikator status sosial-ekonomi dalam tingkat rumah tangga. Tingkat status ekonomi (wealth index) yaitu ukuran standar hidup kumulatif dari sebuah rumah tangga yang dihitung berdasarkan kepemilikan rumah 
tangga atas keberadaan beberapa aset barang seperti mobil, TV, dan sebagainya ${ }^{18}$. Tingkat status ekonomi dapat dihubungkan dengan pemanfaatan pelayanan kesehatan dan perilaku pencarian kesehatan (health seeking behavior) yang bervariasi, sehingga jenis ketidaksetaraan sosial yang terjadi di masyarakat dapat menjelaskan hasil penelitian yang menunjukkan bahwa terdapat pengaruh positif antara pemberian ASI eksklusif dan tingkat status ekonomi dan kemungkinan pemberian ASI eksklusif meningkat seiring dengan peningkatan status ekonomi ${ }^{17}$.

Variabel lain yang diteliti dalam penelitian ini antara lain usia ibu, status pekerjaan ibu, daerah tempat tinggal, kunjungan ANC, jenis persalinan, tempat persalinan dan IMD tidak memiliki hubungan dengan pemberian ASI eksklusif. Penelitian Untari (2017) ${ }^{19}$ dan Shaliha, Purwanti dan Arifah (2019) serupa dengan hasil penelitian ini yang menjelaskan bahwa usia ibu tidak memiliki hubungan dengan pemberian ASI ekslusif disebabkan kurangnya pengalaman yang dipunyai ibu tentang ASI eksklusif, kurangnya wawasan ibu mengenai ASI eksklusif dan faktor individu seperti ibu dengan usia lebih muda merasa malu dan kesusahan menyusui di depan umum dan ibu yang usia lebih tua merasa tidak percaya diri dapat produksi ASI yang banyak ${ }^{20}$. Hasil penelitian mengenai status pekerjaan ibu sejalan dengan penelitian Paschalia (2017) yang menjelaskan bahwa status pekerjaan ibu tidak memiliki hubungan dengan pemberian ASI eksklusif disebabkan pemberian MP-ASI dini kepada bayi yang menjadi kebiasaan di masyarakat dan promosi susu formula secara besar-besaran menjadi dorongan bagi ibu untuk memberikan susu formula dibanding $\mathrm{ASI}^{21}$. Hasil penelitian menunjukkan bahwa daerah tempat tinggal tidak memiliki hubungan dengan pemberian ASI eksklusif dan hasil tersebut sejalan dengan penelitian Dwiani, Destriatania dan Mutahar (2014) disebabkan ibu yang tinggal di pedesaan mempunyai waktu lebih banyak untuk menyusui bayinya dibanding ibu yang tinggal di perkotaan yang cenderung bekerja di luar rumah sehingga lebih sering meninggalkan bayi dan mempercepat pemberian MP-ASI dan susu formula ${ }^{22}$.

Hasil penelitian mengenai kunjungan ANC searah dengan penelitian Kirimunun dan Noer (2014) yang menunjukkan kunjungan ANC tidak memiliki hubungan dengan pemberian ASI eksklusif disebabkan kurangnya peran tenaga kesehatan dalam memberikan penyuluhan kesehatan khususnya mengenai ASI eksklusif ${ }^{23}$. Penelitian Hasniati, Indah dan Kasman (2015) serupa dengan hasil penelitian ini yang menunjukkan tempat persalinan tidak memiliki hubungan dengan pemberian ASI eksklusif dikarenakan kurangnya pemahaman ibu mengenai ASI eksklusif, sulitnya menghilangkan kebiasaan ibu dan pendidikan ibu yang rendah ${ }^{24}$. Hasil penelitian mengenai jenis persalinan searah dengan penelitian Fakhidah dan Palupi (2018) yang mengatakan bahwa jenis persalinan tidak memilki hubungan dengan pemberian ASI eksklusif disebabkan ibu yang menjalani persalinan normal memilih untuk diam dan beristirahat daripada segera memberikan ASI walau ibu mengetahui pentingnya ASI bagi bayi ${ }^{25}$. Penelitian Nisrina, Wiyasihati, Fatmaningrum dan Sulitiawati $(2019)^{26}$ serupa dengan hasil penelitian ini yang menyebutkan bahwa tidak adanya hubungan antara IMD dengan pemberian ASI eksklusif, hal tersebut disebabkan adanya variabel lain selain IMD yang berpengaruh dalam pemberian ASI eksklusif seperti umur ibu, pengetahuan dan dukungan keluarga ${ }^{27}$.

Kelebihan dari penelitian ini adalah menggunakan data sekunder yang berasal dari Survei Demografi dan Kesehatan Indonesia Tahun 2017, sehingga data yang digunakan dalam penelitian ini mencakup dari seluruh wilayah Indonesia. Namun, penelitian ini memiliki keterbatasan yaitu variabel yang terpilih dalam penelitian ini hanyalah sebagian kecil dari beberapa faktor yang mempengaruhi pemberian ASI eksklusif, sedangkan masih banyak faktor yang mempengaruhi pemberian ASI eksklusif yang dapat dibahas sehingga diperlukan penelitian lebih lanjut untuk memperdalam penelitian terkait dengan mengganti beberapa variabel yang berbeda agar hasil penelitian menjadi lebih lengkap dan lebih jelas. Keterbatasan lain dalam penelitian ini yaitu dalam pengukuran ASI eksklusif yang diukur berdasarkan informasi riwayat pemberian makanan dan minuman pada bayi usia $0-5$ bulan dalam waktu 24 jam terakhir sebelum survei dilaksanakan. Hal tersebut dapat menyebabkan proporsi bayi yang diberi ASI eksklusif mengalami seditik overestimated dikarenakan beberapa bayi yang diberikan ASI secara teratur mungkin tidak menerimanya dalam 24 jam terakhir yang menyebabkan tidak termasuk dalam perhitungan sebagai bayi yang mendapat ASI eksklusif. Meskipun ada upaya yang dilakukan selama pengumpulan data untuk meminimalkan recall bias namun hal ini tidak dapat dihilangkan ${ }^{28}$.

\section{KESIMPULAN}

Faktor yang paling berpengaruh terhadap pemberian ASI eksklusif diantara 3 variabel yang signifikan yaitu ibu yang mempunyai anak berusia $0-1$ bulan. Berdasarkan kesimpulan maka peneliti merekomendasikan pada pemerintah maupun praktisi kesehatan untuk melakukan upaya peningkatan pengetahuan, salah satunya dapat dilakukan dengan penyuluhan. Sasaran intervensi difokuskan kepada kategori ibu yang memiliki bayi pada kelompok umur $>3$ bulan, tingkat pendidikan rendah dan termasuk dalam tingkat status ekonomi rendah.

\section{ACKNOWLEDGEMENT}

Terima kasih kepada pihak Demograhic and Health Surveys (DHS) Program yang telah mengizinkan kami untuk menganalisis data Survei Demografi dan Kesehatan Tahun 2017 terkait determinan pemberian ASI eksklusif dan kepada pihak Badan Pusat Statistik (BPS), Badan Kependudukan dan Keluarga Berencana Nasional (BKKBN), Kementrian Kesehatan (Kemenkes) dan ICF International yang telah bekerjasama dalam penulisan laporan Survei Demografi dan Kesehatan Indonesia 2017.

\section{REFERENSI}

1. Badan Pusat Statistik, Badan Kependudukan dan Keluarga Berencana Nasional, K. K. \& U. Survei Demografi dan Kesehatan 2017. Jakarta: BPS, $B K K B N$ \& Kementerian Kesehatan https://e- 
koren.bkkbn.go.id/wp-

content/uploads/2018/10/Laporan-SDKI-2017WUS.pdf (2017).

2. World Breast Feeding Week. BREASTFEEDING : A Winning Goal for Life! https://worldbreastfeedingweek.org/2014/pdf/ wbw2014-af-eng-a4.pdf (2014).

3. World Health Organization. Exclusive breastfeeding for optimal growth, development and health of infants. http://www.who.int/elena/titles/complementa ry_feeding/en/ (2020).

4. Peraturan Pemerintah, R. I. Peraturan Pemerintah Republik Indonesia Nomor 33 Tahun 2012. Jakarta: Pemerintah Republik Indonesia (2012).

5. Damayanti, D. Asyiknya minum ASI. (Gramedia Pustaka Utama, 2013)

6. Notoatmodjo, S. Promosi Kesehatan, Teori \& Aplikasi, ed. revisi 2010. Jakarta: Penerbit Rineka Cipta (Penerbit Rineka Cipta, 2010). doi:10.1108/JMTM-03-2018-0075.

7. Suparmi, S., \& Saptarini, I. Determinan Pemberian Asi Eksklusif: Analisis Data Sekunder Survei Demografi Dan Kesehatan Indonesia 2012. Indones. J. Reprod. Heal. 5, 15-21 (2014).

8. Onah, S., Osuorah, D. I. C., Ebenebe, J., Ezechukwu, C., Ekwochi, U., \& Ndukwu, I. Infant feeding practices and maternal sociodemographic factors that influence practice of exclusive breastfeeding among mothers in Nnewi South-East Nigeria: A cross-sectional and analytical study. Int. Breastfeed. J. 9, 1-10 (2014).

9. Kemenkes RI. Laporan Nasional Riset Kesehatan Dasar (Riskesdas) 2018. Jakarta: Kemenkes RI (2018).

10. Seifu, W., Assefa, G., \& Egata, G. Prevalence of exclusive breast feeding and its predictors among infants aged six months in Jimma Town, Southwest Ethiopia, 2013. J. Pediatr. Neonatal Care 1, 1-6 (2014).

11. Ulfah, A., Sahli, Z., Nusadewiarti, A., \& Angraini, D. I. Hubungan Tingkat Pendidikan Dan Pengetahuan Ibu Mengenai Air Susu Ibu (ASI) Dengan Riwayat Pemberian ASI Eksklusif Di Rumah Sakit Ibu Dan Anak Bunda Asy-Syifa Kota Bandar Lampung. J. Major. 3, (2014).

12. Lindawati, R. Hubungan Pengetahuan, Pendidikan dan Dukungan Keluarga dengan Pemberian ASI Eksklusif. Faletehan Heal. J. 6, 3036 (2019).

13. Mogre, V., Dery, M., \& Gaa, P. K. Knowledge, attitudes and determinants of exclusive breastfeeding practice among Ghanaian rural lactating mothers. Int. Breastfeed. J. 11, 1-8 (2016).

14. Roshan, R., Sajjad, S., \& Tanvir, S. Impact of maternal education and source of knowledge on breast feeding practices in Rawalpindi city. MOJ Curr. Res. Rev. Res. 1, 212-242 (2018).

15. Atimati, A. O., \& Adam, V. Y. Breastfeeding practices among mothers of children aged 1-24 months in Egor Local Government Area of Edo State, Nigeria. South African J. Clin. Nutr. 33, 1016 (2020).

16. Ihudiebube-Splendor, C. N., Okafor, C. B., Anarado, A. N., Jisieike-Onuigbo, N. N., Chinweuba, A. U., Nwaneri, A. C., ... \& Chikeme, P. C. Exclusive breastfeeding knowledge, intention to practice and predictors among primiparous women in Enugu South-East, Nigeria. J. Pregnancy 2019, 1-8 (2019).

17. Tariku, A., Alemu, K., Gizaw, Z., Muchie, K. F., Derso, T., Abebe, S. M., ... \& Tsegaye, A. T. Mothers' education and ANC visit improved exclusive breastfeeding in Dabat health and Demographic surveillance system site, northwest Ethiopia. PLoS One 12, 1-13 (2017).

18. Mawa, R., Nabasirye, C. K., Mulira, J., Nakidde, C., K. et al. Socio-Economic Status and Exclusive Breastfeeding Among Infants in a Ugandan Cross-Sectional Study. J. Food Nutr. Sci. 7, 16-24 (2019).

19. Untari, J. Hubungan antara Karakteristik Ibu dengan Pemberian ASI eksklusif di Wilayah Kerja Puskesmas Minggir Kabupaten Sleman. J. Formil (Forum Ilmiah) KesMas Respati 2, 17-23 (2017).

20. Shaliha, A. M., Puwanti., \& Arifah, I. Hubungan Karakteristik Ibu, Pengetahuan, Dukungan Suami dan Dukungan Keluarga terhadap Praktik Pemberian ASI Eksklusif di Wilayah Kerja Puskesmas Purwodadi 1 Kabupaten Grobogan. (Universitas Muhammadiyah Surakarta, 2019).

21. Paschalia, Y. P. M. ANALISIS FAKTOR-FAKTOR YANG MEMPENGARUHI PEMBERIAN ASI EKSKLUSIF PADA BAYI DI PUSKESMAS ReWARANGgA. J. Kesehat. Prim. 2, 141-152 (2017).

22. Dwiani, A., Destriatania, S., \& Mutahar, R. Analisis Faktor-Faktor Yang Berhubungan Dengan Pemberian Asi Eksklusif Di Puskesmas Dempo Palembang Dan Puskesmas Simpang Timbangan Ogan llir 2012. J. Ilmu Kesehat. Masy. 5, 9-18 (2014).

23. Kirimunun, M. P., \& Noer, E. R. Hubungan Frekuensi Kunjungan Anc (Ante Natal Care) Dengan Riwayat Pemberian Asi Pada Bayi Usia 6 Bulan. J. Nutr. Coll. 3, 730-736 (2014).

24. Hasniati, Y., Indah, M. F., Asrinawaty, A., \& Kasman, K. Determinan Pemberian Asi Eksklusif di Kabupaten Barito Kuala Kalimantan Selatan. Media Kesehat. Masy. Indones. 11, 39-43 (2015).

25. Fakhidah, L. N., \& Palupi, F. H. Analisis Faktor Yang Mempengaruhi Pemberian Asi Eksklusif. J. Kebidanan 10, 181-192 (2018).

26. Nisrina, V. D., Wiyasihati, S. I., Fatmaningrum, W., \& Sulistiawati, S. The Relationship between Early Initiation of Breastfeeding and Exclusive Breastfeeding in the Work Area of Wiyung Public Health Center, Surabaya. JUXTA J. IIm. Mhs. Kedokt. Univ. Airlangga 10, 48-51 (2019).

27. Sohimah., Lestari, Y. G. ANALISIS FAKTOR YANG 
MEMPENGARUHI PEMBERIAN AIR SUSU IBU (ASI) EKSKLUSIF DI WILAYAH KERJA PUSKESMAS CILACAP TENGAH I KABUPATEN CILACAP TAHUN 2017. Bidan Prada J. Publ. Kebidanan Akbid YLPP Purwokerto 8, 125-137 (2017).

28. Arage, G., \& Gedamu, H. Exclusive breastfeeding practice and its associated factors among mothers of infants less than six months of age in Debre Tabor Town, Northwest Ethiopia: a crosssectional study. Adv. Public Heal. 2016, 1-7 (2016). 